\title{
Analysis on Present Situation and Influencing Factors of Cash Holding of Coal Listed Companies
}

\author{
Xinhong Wang ${ }^{1}$, Huan Liang ${ }^{1, a}$ \\ ${ }^{1}$ School of Xi'an University of Science and Technology, Xi'an 710054, China. \\ a279648894@qq.com
}

\begin{abstract}
This paper selects 209 sample data of 27 coal listed companies in Shanghai and Shenzhen from 2009 to 2016 for empirical analysis. According to the research, the cash holding level of China's coal listed companies is mainly between $5 \%$ and $15 \%$. Financial leverage, company size and cash holdings are negatively correlated. Cash flow, return on net assets are positively correlated with cash holdings. According to the results of empirical research, in the current environment of the sluggish development of the coal industry, it is recommended that coal listed companies maintain an appropriate financial leverage ratio to ensure continuous cash flow, thus ensuring continued operations. At the same time, it is proposed to rationally plan existing funds and conduct feasibility assessments on investment projects.
\end{abstract}

Keywords: Coal listed companies, cash holdings, current situation, influencing factors.

\section{Introduction}

\subsection{Research Background}

With regard to the research on the cash holdings of listed companies, China is still in its infancy, the depth and breadth of research are lacking. Western academic circles have achieved good research results, but mainly for the Western market system, can not be fully used to analyze China's problems, but can provide theoretical basis and research methods for our research. China's capital market is still a young market,it should consider the corporate governance environment and legal environment in China to conduct research and analysis. If the cash holdings are too high or too low, it will have an impact on the company, determining the appropriate cash holdings is crucial to the company's development. Compared with the cash holdings of foreign listed companies, cash holdings in listed companies in our country are generally high, with a tendency to rise first and then decline. In addition, due to the lack of proper estimation and evaluation of the company's development status, some listed companies in China will have extreme conditions of excessive cash holdings or shortages, which will be detrimental to the healthy development of the company. At present, China's coal enterprises have great arbitrariness in cash holding in the practice of production and management. On the one hand, the inventory and accounts receivable occupy funds, so that some funds are idle and precipitated, and the profit opportunities are lost. On the one hand, there is a shortage of cash, in order to keep the company running continuously, the company has to borrow a lot of money, which poses certain risks to the company. More importantly, there is currently a problem of overcapacity in the coal industry, which is unlikely to reverse in the short term. In this environment, how to determine the optimal cash holdings is crucial.

\subsection{Research Purposes and Significance}

In recent years, China's coal industry is facing a very serious situation. During the "13th FiveYear Plan" period, the coal industry plans to establish an exit mechanism to promote mergers and acquisitions as soon as possible. Under such a large environment, Some coal enterprises with large scale, low added value of products and overcapacity in the industry will face a huge crisis, many coal companies prefer to lose money and are not willing to stop production, because the cash flow chain of business caused by the suspension of production will make the company's situation more difficult. In order to solve these problems and reduce the risk of coal enterprises, it is of great theoretical and practical significance to study the status quo and influencing factors of cash holdings of listed coal companies. 
The purpose of this paper is to investigate and analyze the current status and influencing factors of cash holdings of listed coal companies, and to find out the current problems of enterprises through the current situation investigation, so that enterprises can find the solution to the problem. Through the analysis of the factors affecting the cash holdings, the main factors are found, and then the solutions are sought from the factors.

\section{Literature Review}

The problem of cash holdings is an important research topic of enterprise financial management. In recent years, western scholars have conducted a lot of theoretical and empirical studies on this issue, and obtained rich research results. Although China has less research in this area than abroad, but many Chinese scholars have also done a lot of research and investigation work in this field, and obtained certain research results.

\subsection{Status of Foreign Research}

There are many research conclusions about cash holdings abroad. The typical research conclusions include trade-off theory and cash holdings, information asymmetry, high-quality financing theory and cash holdings, corporate governance structure and cash holdings, institutional environment and cash holdings, bank-enterprise relationships and cash holdings.

Dittmar et al.'s research found that differences in governance environments, such as different national legal systems, have a significant impact on a company's cash holdings. In countries where shareholders' equity is weakly protected, firms hold higher amounts of cash. Ferreira Ferreira et al., after considering the legal protection of shareholders' interests, the legal protection of creditors' interests and the quality of law enforcement, also believe that those countries that have a higher degree of protection for investors' interests have relatively small amounts of cash. Harford et al.'s research suggests that when corporate governance and shareholder interests are better protected, shareholders are more powerful and agency issues are less prominent. In this case, shareholders often allow managers to hold more cash.

Almeida et al. (2004) used American manufacturing companies as a research sample to divide the company into financing-constrained and non-financial-constrained models, empirically testing the relationship between cash holdings and cash flows, and the financial status of the company's cash flow to the company. The study found that companies with financing constraints have more cash than non-financing-constrained companies, and financing-constrained companies are more likely to reserve more cash during a recession.

\subsection{Status of Domestic Research}

Xie Bangsheng, Wei Yuanzhu (2011) analyzed the 264 sample data of China's pharmaceutical manufacturing listed companies from 2007 to 2010. The research proves that the company's cash holdings and cash substitutes, financial leverage, management shareholding ratio, bank debt ratio and the legal environment changes in the opposite direction, in line with the changes in the company's dividend payment and the degree of marketization of the financial industry.

Guan Aili (2011) concluded through descriptive statistics and regression analysis that equity concentration, there is a significant positive correlation between equity concentration and the proportion of outstanding shares and cash holdings; The proportion of legal person shares, management shareholding ratio and cash holdings are significantly negatively correlated; there is no significant relationship between board size and cash holdings. Li Mi (2011) conducted a study on the optimal cash holdings of coal enterprises, and initially discussed the method for determining the optimal cash holdings of coal enterprises. The current situation and problems of cash holdings in coal enterprises are briefly described. the factors affecting the cash holdings of coal enterprises are qualitatively analyzed, and suggestions on how to find the best cash holdings are put forward.

Liu Peng (2014) started from the level of corporate governance. The study found that the company's cash holdings increased with the increase of corporate governance, that is, the corporate 
governance level was positively correlated with cash holdings. At the same time, it proves that cash holdings will affect the company's value.

Yang Jie (2015) takes the Shenzhen GEM listed companies as the research object from 2010 to 2013, and starts from the perspective of the quality of information disclosure with less research results. The research finds that the quality of information disclosure will have a positive impact on cash holdings, the higher the quality of information disclosure, the less cash the company holds.

It can be seen from reading the literature that whether domestic or foreign, the relevant theoretical research on the impact of cash holdings mainly focuses on three aspects: agency theory, financing priority theory and trade-off theory. As can be seen from the literature, analysis of the influencing factors of cash holdings mainly from three major aspects, they are the company's management level, corporate governance structure and external environment. In the analysis of the factors affecting cash holdings, most of the references used regression analysis.

\section{Analysis of the Current Cituation of Cash Holdings of Coal listed Companies}

\subsection{Overall Analysis of Cash Holdings of Coal listed Companies}

At present, China's coal industry is in a development bottleneck, reasonable and effective use of cash to accurately determine the optimal cash holdings of an enterprise is of paramount importance to coal companies. As can be seen from the relevant literature, there are many ways to express cash holdings, and most of them quantify the cash holdings as the level of cash holdings. This paper uses the ratio of the sum of cash and cash equivalents of coal listed companies to total assets to represent the level of cash holdings. In order to analyze the level of cash holdings of coal listed companies, it is necessary to understand the current cash holding status of listed coal companies.

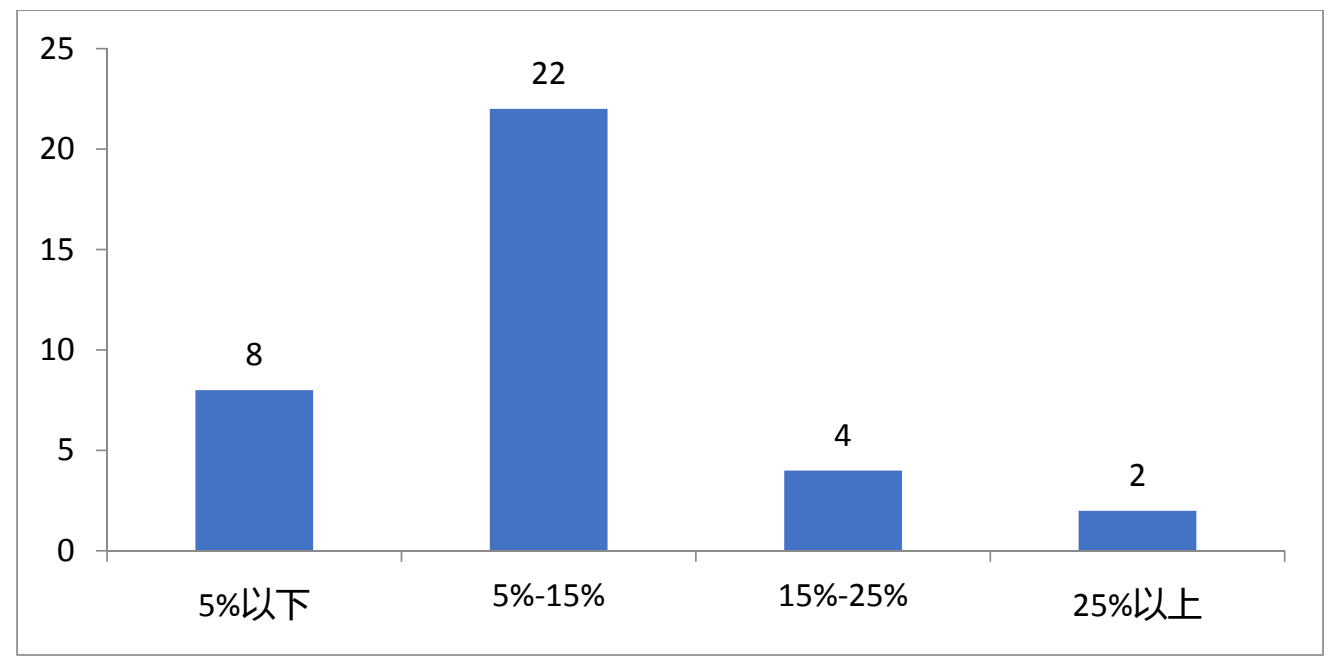

Figure 1. Distribution of cash holdings

According to the data obtained from the consolidation, it can be seen that the cash holding level of China's coal listed companies is in the range of $0.58 \%-56.51 \%$.Figure 1 visually shows the current distribution of cash holdings of coal listed companies in China.As can be seen from Figure 1, there are 8 companies with a cash holding level below 5\%, 22 companies with a cash holding level between $5 \%$ and $15 \%$, there are 4 cash holding levels between $15 \%$ and $25 \%$, and 2 in cash holdings above $25 \%$. It can be seen that the cash holding level of China's coal listed companies is mainly concentrated between $5 \%$ and $15 \%$, and the phenomenon that the cash holding level is too high or too low is not obvious. 


\subsection{Analysis of Solvency and Cash Holdings}

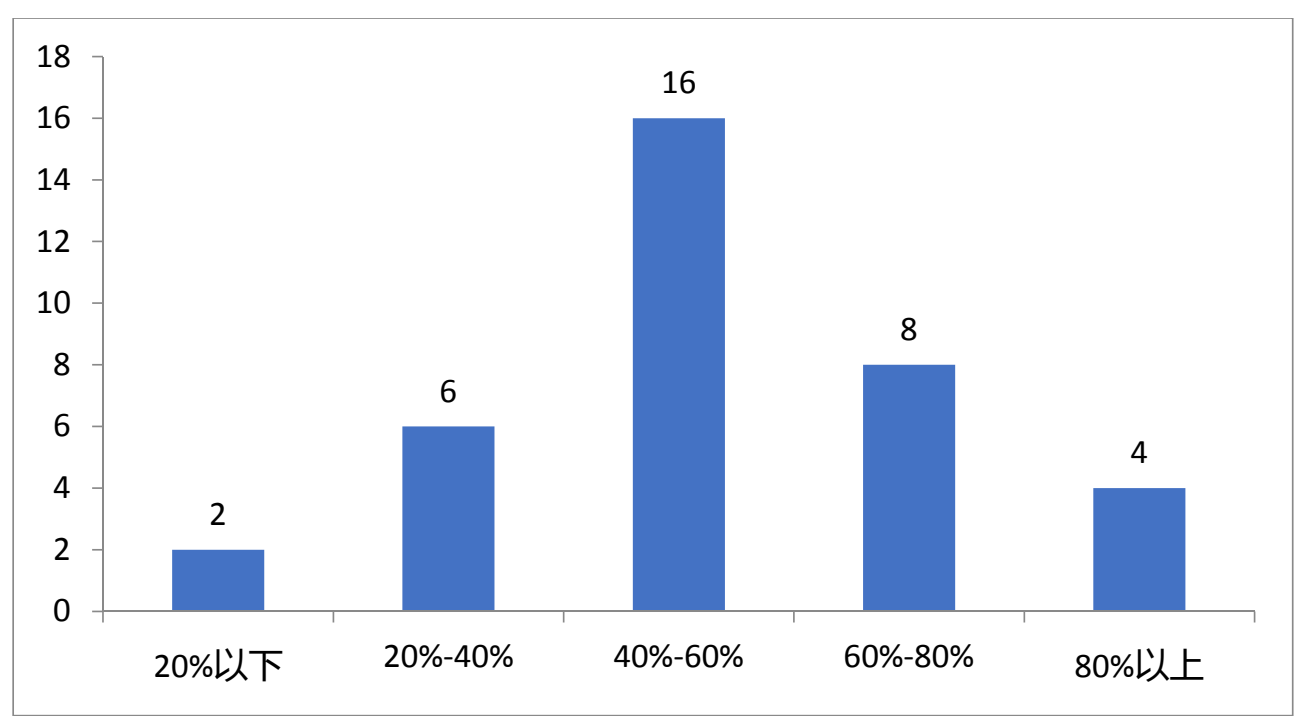

Figure 2. Distribution of assets and liabilities ratio

This paper uses the asset-liability ratio to indicate the solvency of the company. As can be seen from Figure 2, the asset-liability ratio of coal listed companies is mainly concentrated between $40 \%$ and $60 \%$. Combined with the data analysis of 3.1 , it can be seen that when the asset-liability ratio is below $60 \%$, the corresponding cash holding level is concentrated between $5 \%$ and $15 \%$, and when the asset-liability ratio is above $80 \%$, the corresponding cash holding Levels are concentrated in the range of less than or slightly more than $5 \%$. So it can be seen that the current cash holdings of China's coal listed companies are negatively correlated with the asset-liability ratio.

\subsection{Analysis of Operating Income and Cash Holdings}

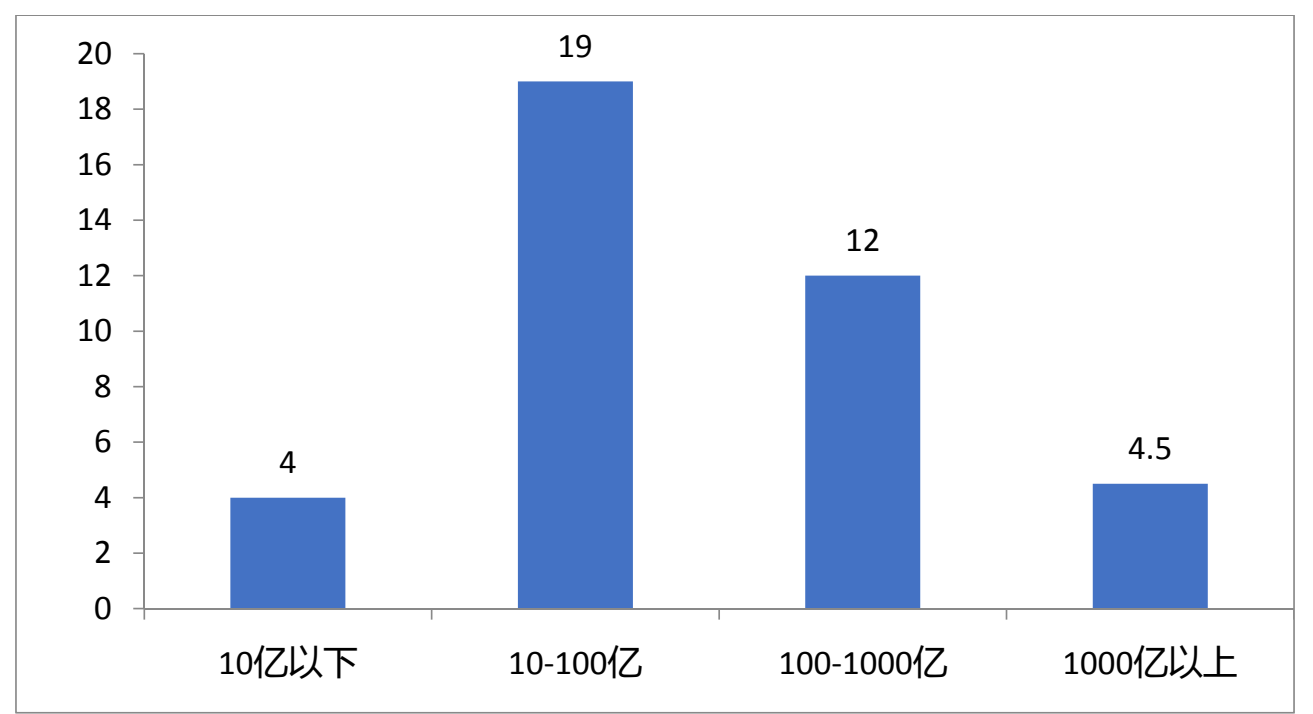

Figure 3. Business income distribution map

As can be seen from Figure 3, the operating income of most coal listed companies is concentrated between 100-100 billion. When the operating income is below 1 billion, the corresponding cash holding level is close to $5 \%$. When the operating income is between 10 and 10 billion, the cash holding level is mainly concentrated between $5 \%$ and $15 \%$. When the operating income is between 100 and 100 billion, the cash holding level is mainly concentrated at 5\%-15. \%between. When the operating income is more than 100 billion, there is only one corresponding coal listed company, and the cash holding level is $7 \%$. It can be seen that the current cash holding level of China's coal listed companies is positively correlated with changes in operating income at a certain level of operating income. 
To analyze the current situation of cash holdings of coal listed companies, in addition to the above-mentioned intuitive description of the current situation, it is also necessary to understand the problems in the cash holding of coal listed companies. In the production and operation process of coal enterprises, most coal enterprises have no clear plans and corresponding management systems for cash holding problems.Due to the current sluggish development of the coal industry, most coal enterprises are in a state of loss, The supply and demand relationship in the market has had a serious impact on the sales of coal products, resulting in a large backlog of coal products. The inventory and accounts receivable of the enterprise occupies too much funds, which makes some funds idle and precipitated, and loses profit opportunities. The problem of excessive debt of some coal listed companies brings greater risks to the development of enterprises.

\section{Empirical Analysis of Factors Affecting Cash Holdings}

\subsection{Research Hypothesis}

The cash held by the company actually comes from the company's cash flow, so the company's cash flow can replace cash holdings to some extent. The more cash flow generated by the company, the stronger the ability to cope with the financial crisis, in the future development of the company, the capital needs of all aspects can be met by the cash flow of the enterprise. Therefore, the more cash flows, the less cash holdings the company has. Based on this point of view, the following assumptions are made:

Hypothesis 1: Corporate cash flow is negatively correlated with cash holdings

From the microeconomic level, when the funds within the enterprise cannot meet the needs of production, operation or investment, enterprises can borrow money to raise funds for enterprise development. The stronger the external financing ability, the greater the financial leverage of the enterprise, indicating that the stronger the ability of the company to raise funds, the smaller the amount of cash that needs to be held. Therefore, the following assumptions are made:

Hypothesis 2: Corporate financial leverage is negatively correlated with cash holdings

From the perspective of company size, compared with small companies, large companies have more diversified operations and are more resistant to risks. In addition, large companies have relatively more information disclosure, which helps to reduce the problem of information asymmetry, so large companies are more likely to achieve external financing at lower cost and less restrictions, and their cash holdings may be lower. From this perspective, the following assumptions are made:

Hypothesis 3: Corporate cash flow is negatively correlated with cash holdings

The return on net assets reflects the level of return on shareholders' equity. It is used to measure the efficiency of the company's use of its own capital. The higher the indicator, the higher the return from investment. This indicator reflects the ability of free capital to obtain a net return. When the return on net assets is high, companies may hold more cash for subsequent investments in order to continue to make a profit, so the following assumptions can be made:

Hypothesis 4: Corporate cash flow is negatively correlated with cash holdings

\subsection{Sample Selection and Data Sources}

This paper selects 209 samples of 27 coal listed companies in Shanghai and Shenzhen stock markets (2009-2016). In order to achieve the expected research objectives, exclude ST companies and companies that do not have accurate financial data. The data in this article is from Guotaian Database, Juchao Information Network, Sina Finance, and the websites of Shenzhen Stock Exchange and Shanghai Stock Exchange. The data is processed by SPSS22.0.

\subsection{Variable Design}

\subsubsection{Interpreted Variables}

The purpose of this paper is to understand the current status of cash holdings of listed coal companies and analyze their influencing factors. In the process of empirical analysis, the cash holding 
level is used instead of the cash holding amount as an explanatory variable. In the research of this paper, the cash holding level is replaced by the ratio of the sum of cash and cash equivalents to the total assets.

\subsubsection{Interpreting Variables}

(1) Cash flow (X1). The ratio of annual operating net cash flow to sales revenue is used to represent the company's cash flow.

(2) Company size (X2). This paper represents the size of the company in terms of the natural logarithm of the total assets of coal listed companies.

(3) Financial leverage (X3). Financial leverage is expressed in terms of asset-liability ratio.

(4) Return on net assets (X4). The return on net assets is expressed as the ratio of net profit to net assets.

This paper studies the symbols and definitions of variables, as shown in Table 4-1:

Table 1. Variable Symbols and Definition Table

\begin{tabular}{cccc}
\hline & variable & symbol & Measure \\
\hline Explained & Cash holding level & $\mathrm{Y}$ & Cash and cash equivalents / total assets \\
variable & cash flow & $\mathrm{X}_{1}$ & Operating net cash flow / sales revenue \\
solution & Financial leverage & $\mathrm{X}_{2}$ & Total liabilities / total assets \\
release & Company Size & $\mathrm{X}_{3}$ & Natural logarithm of total assets \\
change & Roe & $\mathrm{X}_{4}$ & Net profit / net assets \\
the amount & &
\end{tabular}

\subsection{Establishing a Multiple Regression Model}

Based on the assumptions presented above and the definition of variables in 4.3 , the following multiple regression models were established:

$$
Y=\alpha_{0}+\beta_{1} X_{1}+\beta_{2} X_{2}+\beta_{3} X_{3}+\beta_{4} X_{4}+\varepsilon
$$

In the above model, $\alpha_{0}$ is the intercept, $\beta_{\mathrm{i}}$ is the regression coefficient to be estimated, and $\varepsilon$ is the random interference term of the model.

\subsection{Sample Descriptive Statistical Analysis}

Before returning to the cash holdings of listed coal companies, an overall descriptive statistical analysis of the selected sample company data was conducted.These factors are analyzed for the correlation of cash holdings, and the relationship between them is initially explored.

Table 2. Descriptive statistical analysis of sample variables

\begin{tabular}{ccccc}
\hline digital & & Minimum & Maximum & Average value \\
\hline Cash holding level & 209 & .001207 & .725129 & .13437849 \\
Cash flow & 209 & -.909222 & .653767 & .14173677 \\
Financial leverage & 209 & .112440 & .941144 & .48580506 \\
Company Size & 209 & 19.702231 & 27.040367 & 23.419358 \\
Roe & 209 & -2.790081 & .417376 & .08699266 \\
\hline
\end{tabular}

As can be seen from the table:

(1) As can be seen from Table 4-2, the cash holding levels of different coal listed companies vary from 2009 to 2016. Specifically, during the time period when the sample data is selected, the average value of the cash holding level is $13.44 \%$, the maximum value is $72.51 \%$, and the minimum value is $0.12 \%$. The maximum and minimum values of the cash holding level in the 8 years are quite different. It shows that under the same economic conditions, each company has great control over the cash holding level because of its different business strategies and development directions.

(2) From the perspective of company management, the difference in cash flow is relatively large, ranging from $-90.92 \%$ to $65.38 \%$. Although the difference is large, the average value of cash flow is $14.17 \%$, it shows that the cash flow generated by most coal listed companies' operating activities accounts for a relatively large proportion of sales revenue. The average financial leverage of the 
company is $48.58 \%$, which indicates that the total assets of most coal listed companies in China are reasonable and the long-term solvency is better.

\subsection{Correlation Test}

The collinearity test of the samples is to test whether there are collinearity problems between the multiple independent variables involved in this paper. The specific test method is to use the Pearson correlation coefficient to analyze whether there is a correlation between variables. Table 4-3 shows the correlation coefficients between the variables.

Table 3. Sample data correlation analysis results

\begin{tabular}{c|c|c|c|c|c}
\hline & Cash holding level & Cash flow & Financial leverage & Company Size & Roe \\
\hline Cash holding level & 1 & & & & \\
\hline Cash flow & $.219^{* *}$ & 1 & & & \\
\hline Financial leverage & $-.397^{* *}$ & $-.307^{* *}$ & 1 & & \\
\hline Company Size & $-213^{* *}$ & .083 & .124 & 1 & \\
\hline Roe & $.192^{* *}$ & $.420^{* *}$ & $-.370^{* *}$ & .055 & 1 \\
\hline
\end{tabular}

Analysis of the data in Table 4-3 shows that the two independent variables with the highest correlation coefficient are the return on net assets and cash flow, the correlation coefficient has a value of 0.42 and there is a positive correlation between the two variables. The correlation coefficient between company size and ROE is the smallest, and the correlation coefficient is 0.055 , there is a positive correlation between the two variables. Most of the correlation coefficients between the other variables are small. It can be seen that the correlation coefficients between the variables are less than 0.5 , so there is no multi-collinear problem between the coefficients.

\subsection{Multiple Linear Regression Results and Analysis}

Linear regression analysis is used in the analysis of this paper, it is used to describe the linear dependencies between variables. Because the impact of cash holdings of coal listed companies involves many aspects, this paper uses multiple linear regression models for analysis. Tables 4-4 and 4-6 are the results of multiple regression analysis.

Table 4. Model Summary

\begin{tabular}{|c|c|c|c|c|c|c|c|c|c|c|}
\hline \multirow{2}{*}{ Model } & \multirow{2}{*}{$\mathrm{R}$} & $\mathrm{R}^{2}$ & \multirow{2}{*}{$\begin{array}{c}\text { Adjusted } \\
\mathrm{R} \text { square }\end{array}$} & $\begin{array}{c}\text { Standard } \\
\text { valuation } \\
\text { error }\end{array}$ & \begin{tabular}{c}
$\mathrm{R}$ \\
\cline { 5 - 8 } \\
chuare \\
change
\end{tabular} & $\begin{array}{c}\mathrm{F} \\
\text { change }\end{array}$ & $\mathrm{df1}$ & $\mathrm{df2}$ & $\begin{array}{c}\text { Significant } \\
\text { F change }\end{array}$ & Durbin- \\
Watson(U) \\
\hline $\mathrm{I}$ & $.448^{*}$ & .200 & .181 & .097912890 & .200 & 10.131 & 5 & 202 & .000 & 2.271 \\
\hline
\end{tabular}

Table 5. Results of regression analysis

\begin{tabular}{cccccc}
\hline & \multicolumn{2}{c}{ Non-standardized coefficient } & Standard coefficient & & \\
\cline { 2 - 4 } Model & $\mathrm{B}$ & Standard error & $\beta$ & $\mathrm{t}$ & significance \\
\hline (constant) & .542 & .113 & & 4.795 & .000 \\
Cash flow & .080 & .046 & .124 & 1.734 & .084 \\
Financial leverage & -.224 & .048 & -.327 & -4.676 & .000 \\
Company Size & -.013 & .055 & -.172 & -2.422 & .016 \\
Roe & .014 & .031 & .033 & .451 & .652 \\
\hline
\end{tabular}

Table 6. Correlation between expected correlation and regression analysis results

\begin{tabular}{cclc}
\hline Explanatory variables & Mathematics Symbol & Expected correlation & Actual Results \\
\hline Cash flow & $\mathrm{X}_{1}$ & Negative correlation & + \\
Financial leverage & $\mathrm{X}_{2}$ & Negative correlation & - \\
Company Size & $\mathrm{X}_{3}$ & Negative correlation & - \\
Roe & $\mathrm{X}_{4}$ & Positive correlation & + \\
\hline
\end{tabular}


First, from the above regression analysis results, the following regression equation can be obtained:

$\mathrm{Y}=0.542+0.124 \mathrm{X}_{1}-0.327 \mathrm{X}_{2}-0.172 \mathrm{X}_{3}+0.092 \mathrm{X}_{4}$

From the regression results of the respective variables, some of the results are the same as the expected results, but there are some discrepancies. The specific analysis is as follows:

(1) The correlation between cash flow and cash holdings is contrary to the assumption, and the two have a positive correlation. This result shows that when the cash flow level of the enterprise is high, the cash holdings of the enterprise will be correspondingly reduced; When the cash flow level is low, the company's cash holdings will increase accordingly.

(2) The correlation between company size and cash holdings is consistent with the assumptions. The two are negatively correlated at the significance level of 0.016 . From the empirical results, it can be seen that the large companies have stronger anti-risk capabilities, and the shortage of funds is not easy to appear in large companies. Compared with small companies, large companies have a better reputation, so the financing channels are wider, the financing costs are lower, and the ability to use external funds to solve the crisis is stronger, so the cash holding level of large companies will be lower.

(3) The correlation between financial leverage and cash holdings is consistent with the assumptions, and the two are negatively correlated. The financial leverage ratio of the enterprise is consistent with the asset-liability ratio of the enterprise, reflecting the long-term solvency of the enterprise. The negative correlation between financial leverage and cash holdings indicates that the stronger the long-term solvency of an enterprise, the higher the credit rating, and the less cash holdings it has.

(4) The correlation between the return on net assets and the cash holdings is consistent with the assumptions. The two are positively correlated, but the significance is 0.652 , indicating that the return on net assets will have an impact on the level of cash holdings, but the impact is not large. Although the relationship is not high, but it can also be said that when the company's ROE is higher, the company will increase the cash holdings in order to grasp better investment opportunities in a timely manner.

In addition to the above factors, the external environment will also have an impact on the cash holdings of coal listed companies. The factors affecting the cash holdings of the external environment mainly include three aspects, namely the impact of macroeconomic policies, the impact of competitive environment and the influence of other external factors. At present, the research on the factors affecting the cash holdings mainly focuses on the internal factors of the enterprise. There are few studies on the factors affecting the cash holdings of the external environment. Based on the literature, this paper conducts a qualitative analysis of the impact of cash holdings in the external environment. From a macroeconomic point of view, when macroeconomic prosperity and fiscal policy are loose, listed companies hold less cash, and vice versa.

From the perspective of institutional environment, the higher the degree of protection of shareholders and creditors, the more secure the interests of shareholders and creditors, at this time, shareholders and creditors are more effective in restraining agents, so the cash holdings of enterprises are relatively low. When the economic environment fluctuates greatly, companies will choose hold more cash in order to cope with instability. This paper mainly conducts empirical research on the factors of the company's management level and corporate governance structure, the impact on external factors is only the above simple qualitative analysis. .

\section{Research Conclusions and Recommendations}

This paper confirms the impact of the influencing factors of China's coal listed companies on the company's management level and corporate governance level on cash holdings through empirical research, and qualitatively analyzes the impact of external environment on cash holdings. Based on the above studies, this section summarizes the process of descriptive statistics and regression analysis and proposes strategies for optimizing cash holdings. 


\subsection{Research Conclusions}

This paper uses 209 research samples from 27 coal listed companies (2009-2016) in Shenzhen and Shanghai to verify the relationship between the company's management level and the factors of corporate governance structure and cash holdings through empirical analysis, the following conclusions:

Financial leverage, company size and cash holdings are significantly negatively correlated. This shows that the higher the financial leverage of the enterprise, the less the cash holdings. The higher the credit rating of the enterprise, the stronger the company's ability to borrow, so the company tends to hold a lower level of cash. Cash flow is significantly positively correlated with cash holdings, indicating that the more cash flows, the higher the company's cash holdings.

The return on net assets is positively correlated with the cash holdings. Although the results prove that the two are not significantly related, the return on net assets will affect the cash holdings to a certain extent. When the company's return on net assets increases, cash holdings will also increase to some extent.

\subsection{Optimization of Cash Holdings of Coal Listed Companies}

This paper analyzes the factors affecting the cash holdings of coal listed companies, and proposes improvement suggestions based on the conclusions of the above analysis.

Financial leverage, company size and cash holdings are negatively correlated. The size of the company is an established factor and cannot be changed in the short term. Therefore, no improvement proposals are proposed for the size of the company. The company's financial leverage is expressed in terms of asset-liability ratio, reflecting the company's long-term solvency. If this ratio is too low, it indicates that the company's operation and management is conservative. At present, the sluggishness of the coal industry has led to a shortage of cash for most coal companies. Coal companies can expand the debt ratio by appropriately expanding the asset-liability ratio so that the company's cash will not be cut off, thus ensuring sustainable operations.

Cash flow and return on net assets are positively correlated with cash holdings. Both can reflect the profitability of enterprises. In order to make full use of cash and improve profitability, it is necessary to conduct feasibility analysis on investment projects of enterprises. avoid investing in projects with a negative net present value.At present, most coal enterprises are in a development dilemma, so it is necessary to do a good job in forecasting economic benefits, make full use of the cash held by enterprises, and avoid losses caused by investment practices.

\section{References}

[1]. Zhang Jun-boo, Zhou Wei-Tao. Study on the Relationship between Cash Holdings and Operating Performance of Listed Companies in Dynamic Environment - Taking Household Appliance Industry as an Example [J]. Financial News .2013,(12): 26-28.

[2]. Sun Jin-Jun, GU Nicking. Chinese Characteristics, Ownership Structure and Cash Holding [J]. Journal of Guangdong Institute of Finance, 2010, (2): 85-95.

[3]. Xiao Ming, Wu Hui-xiang, Zhang Qu, Yan Rue. Study on cash holdings of listed companies in China based on macroeconomic perspective [J]. China Journal of Management Science, 2013, (3): 28-34.

[4]. Xin Dishing, Wei Quanzhou. Experimental Analysis of Factors Affecting Cash Holdings in Enterprises - Empirical Basis from Listed Companies in China's Pharmaceutical Manufacturing Industry [J]. Journal of Fujian Agriculture and Forestry University, 2011 (6): 47-53.

[5]. Liu Wen. Analysis of the best cash holdings of enterprises [J]. Contemporary Economy, 2014, (6): 14-15

[6]. Li Mi. Discussion on the Best Cash Holdings [J]. Coal Economy Research, 2011, (6): 50-52. 
[7]. Guan Yale. Corporate governance structure on the impact of cash holdings [D]. Changchun: Northeast Normal University Master's thesis, 2011, 5.

[8]. Liu Peng. Corporate governance level, cash holdings and corporate value [D]. Chengdu: Southwest University of Finance and Economics, 2014, 4.

[9]. Xin Yawed. Empirical Study on the Factors Affecting Cash Holdings in China's Listed Companies [D]. Xi'an: Master's thesis, Hangman University, 2012, 5.

[10]. REN Rue. Study on the Impact of Governance Structure on Cash Holdings in China [J]; Journal of Nanjing Agricultural University;

[11]. Chen Min. Research on the correlation between cash holdings and R \& D expenditure of listed companies [D]. Hefei: Master's thesis, Anhui University, 2013, 5. 